FACTA UNIVERSITATIS

Series: Linguistics and Literature Vol. 14, $\mathrm{N}^{\circ} 2,2016$, pp. 103-116

DOI: 10.22190/FULL1602103H

\title{
REFUSALS IN THE PRODUCTION OF SERBIAN ESP LEARNERS
}

\author{
UDC 811.111'243
}

\author{
Sabina Halupka-Rešetar ${ }^{1}$, LjiljanaKnežević \\ ${ }^{1}$ Faculty of Philosophy, University of Novi Sad, Serbia \\ ${ }^{2}$ Faculty of Sciences, University of Novi Sad, Serbia
}

\begin{abstract}
Pragmatics plays a very important role in the process of communication, and the speech act of refusal is performed on a daily basis and in a variety of situations, which is why it has been one of the key topics in discourse pragmatic research over the past several decades. The present paper is aimed at establishing which pragmatic strategies Serbian ESP learners use in producing refusals, depending on the social status of the interlocutors. To this end, twenty B1-B2 level ESP students aged between 20 and 22, majoring in Information Science or Mathematics were randomly selected. The research is based on a survey consisting of twelve discourse completion tasks (DCTs), involving the communication situations of refusing a request, an invitation, an offer and a suggestion (of which only the former two are analysed here). The data obtained are classified, analyzed and interpreted based on a modified version of Beebe, Takahashi and Uliss-Weltz's (1990) taxonomy of refusal strategies. The overall results of the research show that the production of the ESP learners tested significantly differs from native speakers' production of refusals. The largest differences are observed with respect to the frequency of usage of direct refusals, providing excuses, reasons and explanations, as well as with respect to adding statements of alternative.
\end{abstract}

Key words: pragmatic competence, discourse pragmatics, speech acts, refusal, English for Specific Purposes

Submitted August 22 $2^{\text {nd }} 2016$, accepted for publication October $19^{\text {th }}, 2016$ Corresponding author: Sabina Halupka Rešetar

Department of English, Faculty of Philosophy, University of Novi Sad, Serbia

E-mail: halupka.resetar@ff.uns.ac.rs 


\section{INTRODUCTION}

One of the key issues dealt with in the field of language teaching, especially over the past two decades, is pragmatic competence, understood as the ability to communicate effectively and "reflected in how learners produce utterances in the target language to communicate specific intentions and conversely, how they interpret the intentions which their utterances convey" (Rintell 1997: 98). Pragmatic competence involves knowledge beyond the level of grammar (Thomas 1983), therefore knowledge of language use cannot be equalled with knowledge of language itself. In other words, pragmatic competence is not part of linguistic competence but a different, albeit no less important, aspect of knowledge of language. This is corroborated by the findings of a number of empirical studies (Cohen and Olshtain 1981; Kasper 1981; House 1982; Wolfson 1981; Blum-Kulka 1982; Thomas 1983) which suggest that second and foreign language speakers might fail to communicate effectively even when they have an excellent grammatical and lexical command of the target language. That grammatical development of adult foreign and second language learners does not necessarily go hand-in-hand with a corresponding level of pragmatic development has also been argued forin the literature (Bardovi-Harlig \& Dörnyei 1997). This, in turn, raises the question of how the pragmatic competence of L2/FL learners can and should be developed. Numerous studies in the area of interlanguage pragmatics have confirmed that the development of pragmatic rules to produce and perceive the language that is appropriate in a given situation appears to be crucial for language learners. The majority of these studies explore speech acts, such as complaining, thanking, offering, apologizing, requesting, inviting, etc.

Speech acts are presumably universal since every language has a means of performing them. However, the conceptualization and the verbalization of specific speech acts may vary significantly from culture to culture (Abed 2011). This fact gives rise to the study of second language speech acts, which is concerned with the linguistic possibilities available in languages for speech act realization and the effect of cross-cultural differences on second language performance and on the interpretation by native speakers of second language speech acts (Wolfson 1989:183). As Kasper (1997) points out, some of the L2/FL pragmatic knowledge (or competence, in our terms) comes for free by virtue of the fact that it is universal (e.g. the organizational principles of conversation, pragmatic intent can be conveyed directly or indirectly, etc.), while other aspects of it are transferable from the learner's L1 (provided there is corresponding form-function mapping between L1 and L2). But pragmatic competence still requires special attention in language teaching given that (a) learners often fail to use their universal or transferable L1 pragmatic knowledge in L2 contexts and that (b) failure to use or interpret language in a way which is appropriate to a given situation may lead to misunderstanding or even to a complete breakdown of communication.

Research has shown that the following areas prove especially problematic for L2/FL learners: indirect responses or implicatures (Bouton 1994, Boersma 1994, Lee 2002, Taguchi 2005, among others), discourse markers and strategies (House and Kasper 1981, Baumgarten \& House 2007, 2010, House 2009, 2013), forms of address (Brown \& Gilman 1960, Braun 1988, more recently Hofäcker 2006 and Lemmerich 2010) and speech acts in different social contexts (starting with the pioneering work of Gumperz 1977, 1979 and Tannen 1981, as well as the CCSARP project in the late 1980s (see Blum-Kulka et al. 1989); for refusals, see the references listed in the next section). The overwhelming 
majority of studies take English as the target language and explore the linguistic possibilities available for speech act realization in the learners' L1 as well as the effect of cross-cultural differences on second language performance and on how native speakers of English interpret language learners' speech acts. However, little has been said so far about the speech act production and pragmatic transfer of learners whose L1 is Serbian. Paunović (2011, 2013) explored intercultural communicative competence in EFL; Savić (2014) has studied politeness in Serbian advanced EFL learners' requests, apologies and refusals; Halupka-Rešetar (2013, 2014a, 2014b, 2015, 2016) has recently explored compliment responses, addresses and the understanding of conversational implicatures in EFL learners, as well as expressing sympathy, requests and request modifications, compliments and apologies in the production of EFL learners. However, to the best of our knowledge, none of the studies so far have focused on speech acts within an ESP context. Therefore, in the present paper, we focus on the speech act of refusals and explore how they are realized in the production of ESP learners whose L1 is Serbian.

The paper is structured in the following way: Section 2 presents the taxonomy of refusals put forward by Beebe, Takahashi and Uliss-Weltz (1990) and employed in this paper. Section 3 gives a brief overview of the interlanguage pragmatic literature on refusals. This is followed by a description of the experiment which was conducted, along with the results of the data obtained in the research and a discussion of these results. The main findings of the paper are summarized in Section 5, followed by suggestions of possible avenues for further research.

\section{TAXONOMY OF REFUSALS}

Drawing on previous research, the informants' refusals in the present paper are analyzed as sequences of semantic formulas, where a semantic formula is defined as 'a word, phrase, or sentence that meets a particular semantic criterion or strategy; any one or more of these can be used to perform the act in question' (Cohen 1996: 265). Given that refusals are often complex constructions, in addition to the head act (the main refusal) they often include pre-refusal strategies and/or post-refusal strategies. The former serve the purpose of preparing the addressee for the upcoming refusal while the latter tend to emphasize, justify, mitigate, or conclude the refusal expressed in the head act. For example, following Takahashi and Beebe (1987), if a respondent refused an invitation to a college professor's house for a party saying "I'm sorry, I have theatre tickets that night. Maybe we could come by later for a drink", this response would be coded as consisting of three formulas: [expression of regret] [excuse] [offer of alternative].

In their study of pragmatic transfer in Japanese ESL refusals Beebe, Takahashi and Uliss-Weltz (1990) proposed the following taxonomy of semantic formulas: 
Table 1 Beebe, Takahashi and Uliss-Weltz's (1990) taxonomy of semantic formulas in refusals

\begin{tabular}{|c|c|c|}
\hline Type & Semantic formula & Example \\
\hline \multirow[t]{3}{*}{ Direct } & Performative & "I refuse" \\
\hline & Nonperformative statement & - “No" \\
\hline & & $\begin{array}{l}\text { - Negative willingness/ability (“I can't/I } \\
\text { won’t." "I don’t think so.”) }\end{array}$ \\
\hline \multirow[t]{17}{*}{ Indirect } & Statement of regret & "I'm sorry..."; "I feel terrible..." \\
\hline & Wish & "I wish I could help you..." \\
\hline & Excuse, reason, explanation & $\begin{array}{l}\text { "My children will be home that night."; } \\
\text { "I have a headache." }\end{array}$ \\
\hline & Statement of alternative & $\begin{array}{l}\text { - I can do X instead of Y (e.g., "I'd rather..." } \\
\text { "I'd prefer...") }\end{array}$ \\
\hline & & $\begin{array}{l}\text { - Why don't you do X instead of Y } \\
\text { (e.g., "Why don't you ask someoneelse?") }\end{array}$ \\
\hline & $\begin{array}{l}\text { Set condition for future or past } \\
\text { acceptance }\end{array}$ & "If you had asked me earlier, I would have..." \\
\hline & Promise of future acceptance & "I'll do it next time"; "I promise I'll..." \\
\hline & Statement of principle & "I never do business with friends." \\
\hline & Statement of philosophy & "One can't be too careful." \\
\hline & Attempt to dissuade the & "It won't be any fun tonight"; \\
\hline & interlocutor (threatening, & "That's a terrible idea!"; \\
\hline & criticizing, letting the interlocutor & "Don’t worry about it."; \\
\hline & off the hook, requesting help, etc.) & "I'm trying my best." \\
\hline & Acceptance that functions as a & - unspecific/indefinite reply \\
\hline & refusal & - lack of enthusiasm \\
\hline & Avoidance & $\begin{array}{l}\text { - nonverbal (silence, hesitation, doing nothing } \\
\text { or physical departure) }\end{array}$ \\
\hline & & $\begin{array}{l}\text { - verbal (topic switch, joke, repetition of part of } \\
\text { request, postponement (e.g. "I'll think about } \\
\text { it.") or hedging (e.g. "Gee, I don't know." "I'm } \\
\text { not sure.") }\end{array}$ \\
\hline
\end{tabular}

Beebe, Takahashi and Uliss-Weltz also added that these refusals may be preceded by adjuncts, which accompany refusals but which cannot by themselves be used to express a refusal, such as:

1. Statement of positive opinion/feeling or agreement ("That's a good idea..." "I'd love to...")

2. Statement of empathy ("I realize you are in a difficult situation.")

3. Pause fillers (uhh/ well/oh/ uhm) and

4. Gratitude/appreciation

In a significant number of studies, the classification proposed by Beebe, Takahashi and Uliss-Weltz (1990) was adopted without modifications, while in others, certain changes were introduced (see Salazar, Safont-Jorda \& Codina-Espurz 2009). In the present study, the semantic formulas produced byESP learners will be analyzed using the taxonomy outlined above to examine to what extent Serbian ESP learners make use of them. 


\section{REFUSALS IN INTERLANGUAGE PRAGMATICS}

As pointed out earlier, speech acts exist cross-linguistically and cross-culturally, but the degrees of politeness and the way a particular speech act is executed can vary to a large extent across languages and cultures. However, apart from this, refusals are known as a 'sticking point' in cross-cultural communication (Beebe, Takahashi \& Uliss-Weltz 1990) also because they are face threatening acts since they essentially represent instances of rejection of the interlocutor's initiation of social interaction, be it an invitation, a request, an offer or anything else. Thus, the way a refusal is worded is extremely important since the possibility of offending the interlocutor is inherent in the act itself (Kwon 2004).

Failure to refuse appropriately can risk damaging the interpersonal relations of the speakers, which is why refusals usually include various strategies to avoid offending one's interlocutor(s). However, once again, different languages and cultures will opt for different strategies to avoid offending the interlocutor. Kwon (2004), for example, has shown that Mandarin Chinese speakers are much less likely to express positive opinion (e. g., 'I would like to ...') in refusing requests than American English speakers because they are concerned that if they express positive opinions, then they will be forced to comply. Similarly, while American English speakers often use softeners (e. g., 'I'm afraid I can't', 'I really don't know') and express gratitude in refusing invitations, offers, etc., speakers of Egyptian Arabic rarely do so. Also, American English speakers have been found to favour more specific reasons in their refusals, while Japanese speakers tend to use reasons that are not specific regarding place, time, or parties (Beebe, Takahashi \&Uliss-Weltz 1990). In addition to being inherently face-threatening acts to the interlocutor because they counter his or her expectations, refusals are typically complex constructions, usually negotiated over several turns and very frequently involve a degree of indirectness to mitigate them. Indirect refusals have an even higher level of complexity because the speaker must choose or create a suitable structure in order to alleviate the inherent face-threatening effects of a direct refusal (Félix-Brasdefer 2009). The form and content of refusals also depends on the type of speech act that elicits them (request, offer, etc). If one adds to all this the societal variables that regularly have to be taken into account in communication (age of interlocutors, relations of social power and distance, gender, degree of imposition, etc.) it becomes clear that refusals require a high level of pragmatic competence, which even linguistically proficient L2/FL learners may not possess.

The first major cross-cultural pragmatic examination of refusal acts was undertaken by Beebe, Takahashi and Uliss-Weltz (1990) to show that pragmatic transfer occurs in the content, regularity and organization of semantic formulas. Nelson et al. (2002) performed an investigation of Egyptian and US English refusals in the two languages separately and simultaneously but with no discussion of interlanguage transfer. In a similar study, Nelson et al. (2002b) challenged the results of previous studies which found that Jordanians used more indirect strategies than Americans. Their study indicated that both Egyptians and Americans used comparable strategies with similar frequency, but these differences in the findings may be the result of a difference in methodology (data collection via written discourse completion tasks versus interviews, since the written form of Arabic is formal and differs significantly from the spoken variety). Kwon (2004) performed a comparative study of English and Korean refusals and found that the same general strategies were used in the two languages but with different frequency of usage and different wording. The Korean informants proved to be more hesitant during the speech act, used more apologies and 
provided more reasons for their refusal than their American peers and also paid much more attention to the interlocutor's status. All these differences present potential pitfalls for Korean EFL learners. Chang (2008) specifically examined refusal acts and their usage in conversations by native Mandarin Chinese speakers learning English and concluded that Americans prefer a more explicit and direct style of discourse that is also assertive while the Chinese avoid the word "no" with great persistence and prefer a more unassertive, indirect and implicit style of communication.

The relevant literature of Serbian ESL/EFL learners' refusals is very scarce, as pointed out before and is contained to only one study (Savić 2014), which explores issues of politeness in Serbian advanced EFL learners' production and perception, specifically that of university students majoring in English, refusals being one of the three speech acts tackled. To the best of the authors' knowledge, there is yet no existing study dealing with the production of refusals of Serbian ESP learners, i.e. learners with a non-English major.

\section{Methodology of the ReSEARCH}

The research presented here was aimed at investigating the extent to which Serbian ESP learners' production of refusals resembles English native speakers' production. Specifically, it sought to establish which semantic formulas are used in Serbian ESP learners' production of the face-threatening speech act of refusal, with what frequency and in what order and how this compares to the production of refusals by native speakers of English. The research was also expected to establish how the speech act used for elicitation and the social status of the interlocutors influence the refusal strategy employed.

The participants in this experiment were twenty (20) undergraduate students from the Department of Mathematics and Informatics (Faculty of Sciences, University of NoviSad) whose L1 is Serbian and were between twenty and twenty-two years of age. None of them had spent extended spans of time (over three months) in an English-speaking country. They were all of an intermediate level of proficiency in English (B1-B2 according to the Common European Framework of Reference), based on the Quick Placement Test (OUP, 2001) which was administered prior to the experiment.

Given that no native speakers of English participated in this experiment, the research instrument was fully replicated from Kwon (2004), who used an open-ended modified version of the 12-item discourse completion test developed by Beebe, Takahashi and UlissWeltz (1990) to test the realization of refusals in twelve male and twenty-five female university students aged between eighteen and twenty-two. The test consisted of situations in which the respondents were required to refuse three requests, three invitations, three offers, and three suggestions (of which we only analyze refusals to invitations and requests in this paper). To test the effects of the variable of social power, each situation type included one refusal to a person of higher status, one to a person of equal status, and one to a person of lower status. Thus, in the experiment, the following six situations were used: 
Table 2 Distribution of the social power variable in the DCTs

\begin{tabular}{lc}
\hline Situation & $\begin{array}{c}\text { Power relation } \\
\text { (informant's perspective) }\end{array}$ \\
\hline Refuse boss's invitation to party (4) & - \\
Refuse friend's invitation to dinner(10) & $=$ \\
Refuse salesman's invitation to dinner (3) & + \\
Refuse boss's request to stay at work late (12) & - \\
Refuse classmate's request for notes (2) & $=$ \\
Refuse worker's request for increase in pay (1) & + \\
\hline
\end{tabular}

The respondents were allowed up to thirty (30) minutes to complete the questionnaire. The test is provided for reference in the Appendix of this paper.

The data analysis proceeded in the following way: the semantic formulas were counted and then classified according to the taxonomy in proposed by Beebe, Takahashi and UlissWeltz (1990) and presented above in Table 1. Next, the frequency of each semantic formula was calculated in each situation (by dividing the number of occurrences of the formula by the number of respondents) and finally, the results of the ESP learners were compared to the results of native speakers of American English. A total of 115 responses were obtained in this experiment, with a total of 241 semantic formulas (2.09 per response, which is considerably lower than the average number of formulas used by American respondents, which is 4.00).

Regarding the typical order of semantic formulas in refusals, the ESP respondents typically started their refusal with an expression of regret, followed by a direct refusal and an excuse or reason for rejecting the interlocutor. Takahashi and Beebe (1987) point out that starting off with regret sounds a little abrupt to the American ear. Felix-Brasdefer (2008:170) also found that among Americans (mostly participants from Minneapolis, Minnesota) a reason or explanation (often prefaced by partial agreements/positive opinion) is the preferred means of refusing in formal and informal situations. However, Kitao (1986) stresses that in British English, a refusal to a request is more likely to be expressed through an apology or an expression of regret followed by a reason or excuse. Thus, it might be the case that the ESP respondents who used an expression of regret before actually refusing the request or invitation were following the British pattern. ${ }^{2}$ Also, note that direct refusals are used quite often by Serbian ESP learners, which might be a consequence of transfer from their L1, given that this type of semantic formula is not featured in the production ofnative speakers of (American) English. The overall findings of the experiment are presented in the following table: ${ }^{3}$

\footnotetext{
${ }^{1}$ The number in parentheses indicates the number of the DCT in the test (see Appendix).

${ }^{2}$ This assumption issupported by the fact that the leading publishing companies providing ESP/EFL teaching material in Serbia are mostly British, e.g.Oxford University Press, Pearson Education, Cambridge University Press, etc. ${ }^{3}$ Elaboration of reason, address forms and statements of solidarity are also featured as semantic formulas in Kwon (2004) but we disregard them here since they were not originally introduced in Beebe, Takahashi and Uliss-Weltz (1990).
} 
Table 3 Frequency of semantic formulas used in refusals by Serbian ESP learners and native speakers of American English

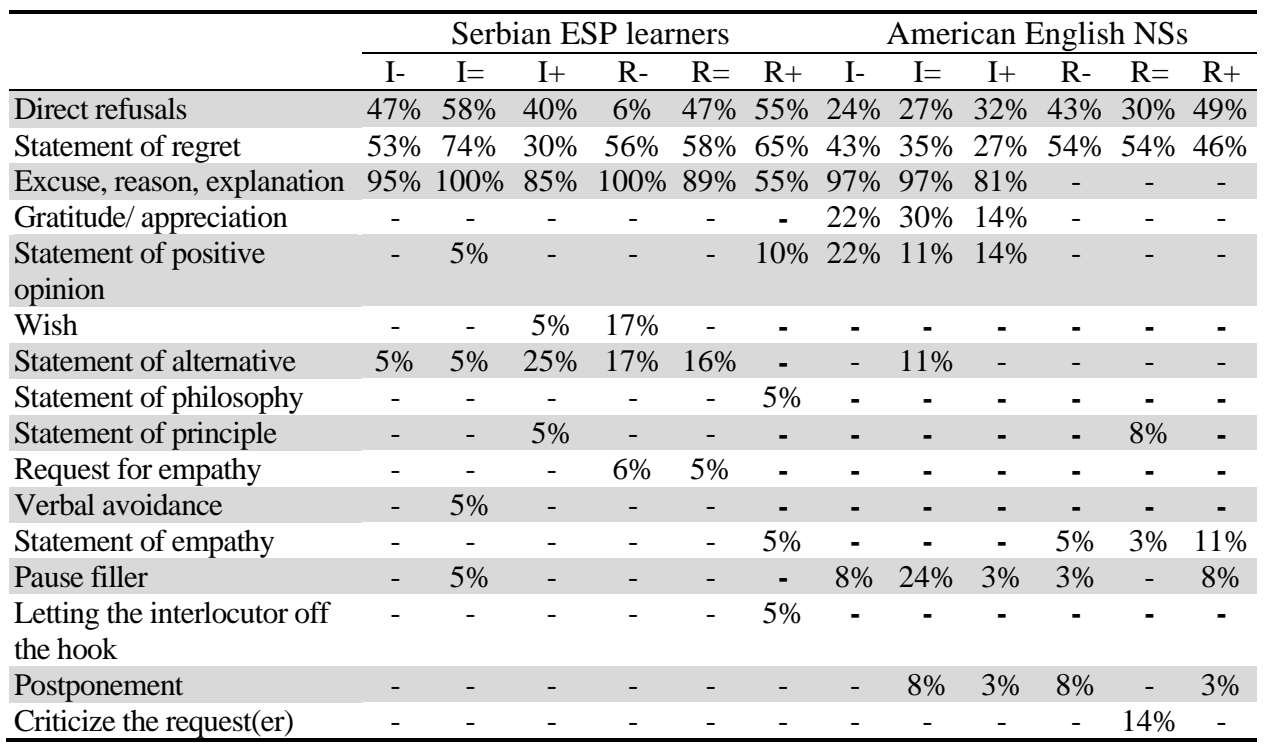

The data in the above table only partly confirm the results of previous research, which has shown that the excuse/reason semantic formula was the most frequent formula in a refusal speech act (e.g. Chang 2008). Namely, that in refusing an invitation, native speakers and the ESP learners who participated in this study provided excuses, reasons and explanations with approximately equal frequency regardless of the social power of the interlocutor (somewhat less frequently with people who are socially inferior, however, for reference, see the I+ columns). However, in refusing a request, not one of the native speakers used this semantic formula, while ESP learners systematically did so with almost equal frequency as in the invitation scenarios. What is also clear from the data in Table 3is that there are significant differences between the production of refusals by native speakers of English and those of the ESP learners who participated in this study. The most obvious difference concerns the significantly higher number of direct refusals produced by ESP learners in the invitation scenario (approximately twice as many with socially inferior or equal interlocutors). However, in the request scenarios the situation is significantly different: it seems that the ESP respondents were reluctant to directly refuse the request of a person who is socially superior (see the R-columns) and often only used an explanation of reason (e.g. I was thinking to go home at the end of the day, I'm really tired; I'm exhausted; I was hoping to go home, my wife is waiting for me), ${ }^{4}$ occasionally supported by a statement of regret (e.g. I'm sorry but I have some important business after; My friends are waiting for me, we go to a party. I'm sorry; I'm sorry, but I already made plans with my family, etc). On the other hand, native speakers are least likely to utter a direct refusal when the interlocutor is equal in social power. Statements of regret (typically $\left(I^{\prime} m\right)$ sorry) occur in the ESP learners' responses somewhat more frequently than in native speakers' responses,

${ }^{4}$ The subjects' responses are given here in the exact form in which they occur in the test. 
but occur significantly more often in the invitation scenario with a socially equal interlocutor. Of the remaining semantic formulas in the ESP learners' responses, statements of alternative appear to occur almost regularly (though with rather low frequency), e.g. We can meet another time; Ask someone else; It's better to leave it for tomorrow, etc. There are also a few examples of expressions of wish (particularly in the R- scenario), e.g. I wish I could but...; I would like to but..., while other formulas are few and far between. This sharply contrasts with the native speakers' production of refusals, which is characterized by a systematic use of expressions of gratitude and statements of positive opinion in the invitation scenarios. Pause fillers are another semantic formula found in the invitation scenarios (especially the I= situation), but not in refusing a request, where a rather insignificant number of respondents from the native speakers' group used statements of empathy instead. These, however, are hardly ever used by any of the ESP learners who participated in the experiment.

Comparing the production of the ESP respondents and that of the native speakers of English, we see that there are many similarities but also some striking differences, not only in refusing a request, but also with respect to the production of refusals to invitations. Generally speaking, the ESP learners who participated in the experiment do not seem to have attained a level of pragmatic competence that would equal their level of linguistic competence. Their production of refusals is characterized by excessive usage of direct refusal strategies and expressions of regret (especially when refusing an invitation) and also by providing an excuse, reason or explanation systematically, regardless of the speech act used to elicit a refusal or the social relations between the interlocutors. For native speakers of English, these two variables (the speech act used to elicit a refusal and the social relations between the interlocutors) influence to a large extent the way a refusal will be worded, as illustrated by the fact that e.g. in refusing a request, excuses, reasons and explanations are never provided. On the other hand, in refusing an invitation, native speakers of English occasionally express their gratitude, add a statement of positive opinion or use pause fillers or postponement to soften the refusal. These semantic formulas are not used by Serbian ESP learners. One final comment concerns statements of alternative. In the experiments, ESP learners used this formula in both types of scenarios. This might be the result of L1 transfer, given that native speakers of English only employed it in the I= situation. In any case, further research is required to characterize precisely the linguistic behaviour of native speakers of Serbian in the speech act of refusing before any sound conclusions can be drawn with respect to what may or may not count as transfer from L1.

\section{CONCLUDING REMARKS}

In this paper, we explored the speech act of refusals in the production of ESP learners whose native tongue is Serbian. Speech acts exist crosslinguistically and crossculturally, but the way a particular speech act is executed can vary to a large extent across languages and culture; therefore, the aim of this research was to establish the degree of pragmatic competence of the respondents by analysing the extent to which their refusals resemble the refusals produced by native speakers of English.

An experiment was conducted using a questionnaire with DCTs in which we manipulated the types of speech acts used for elicitation (requests and invitations) and the relation of social power between the interlocutors. The general conclusion that can be 
drawn from the research is that Serbian ESP learners use considerably more direct refusal strategies than native speakers of English and do not employ expressions of gratitude/ appreciation or statements of positive opinion. This is an important finding, given that due to this, native speakers of English may find Serbian ESP learners rude or impolite. On the other hand, the respondents' production is also characterized by a consistent use of excuses, reasons and explanations - while such behaviour is also typical of native speakers of English, this only extends to refusing an invitation but by no means to refusing a request. Furthermore, while the ESP learners' production is probably the result of analogy in the latter respect, their systematic providing an alternative in refusals is more likely to be the effect of L1 transfer.

The limitations of the present study are numerous. Firstly, the respondents in the study were of the same age and major; therefore, the findings may not be broadly applicable to other age groups or students of other majors (e.g. History, Arts or Agriculture). A larger number of respondents may also have given different results, which could be important for those semantic formulas that did not occur frequently in the existing data. The research instrument (DCT) also has its drawbacks, since some situations may put the informants into roles with which they are unfamiliar and thus create unnatural utterances, and additionally since the space provided on the sheets may constrain the length of the informant's response. However, it is also true that DCTs are an effective means of gathering large amounts of data quickly and are fairly easy to administer. Lastly, there is no existing study of refusals in Serbian which could be used to determine the extent to which the respondents in this study transferred their L1 pragmatic knowledge to English.

In spite of all the limitations pointed out, we feel that the present study contributes to the existing literature of interlanguage pragmatics by discovering some of the shortcomings of Serbian ESP (and EFL) learners' production of refusals in English. The pedagogical implications of the study are thus clear: pragmatic competence has to be developed interlanguage pragmatics can and has to be taught if FL learners are to attain a level of pragmatic competence closely corresponding to their level of linguistic competence. This is equally important both for EFL learners and ESP learners, therefore the syllabus for a modern, use-centred ESP course should be enriched with more authentic materials, which would aid the development of the learners' communicative competence.

Acknowledgement: The first author acknowledges funding from project No. 178002 of the Ministry of Education, Science and Technology of the Republic of Serbia, entitled Languages and Cultures in Time and Space.

\section{REFERENCES}

Abed, A. Q. (2011). Pragmatic Transfer in Iraqi EFL Learners' Refusals. International Journal of English Linguistics, 1/2: 166-185.

Allami, H. \& Naeimi, A. (2011). A Cross-Linguistic Study of Refusals: An Analysis of Pragmatic Competence Development in Iranian EFL Learners. Journal of Pragmatics, 43 (1): 385-406

Bardovi-Harlig, K. \& Dörnyei, Z. (1997). Pragmatic awareness and instructed L2 learning: an empirical investigation. Paper presented at the AAAL 1997 Conference, Orlando.

Baumgarten, N. \& House, J. (2007). Speaker stances in native and non-native English conversation. In: ten Thije, J. \& Zeevaert, L. (Eds.), Receptive Multilingualism. Amsterdam/Philadelphia: John Benjamins, 195-216.

Baumgarten, N., House, J. (2010). I think and I don't know in English as lingua franca and native English discourse. Journal of Pragmatics, 42 (5): 1184-1200. 
Beebe, L., Takahashi, T. \& Uliss-Weltz, R. (1990). Pragmatic transfer in ESL refusals. In R. Scarcella, E. Anderson \& S. Krashen (Eds.), Developing Communication Competence in a Second Language. New York: Newbury House, $55-73$.

Blum-Kulka, S. (1982). Learning to say what you mean in a second language: a study of the speech act performance of Hebrew second language learners. Applied Linguistics 11/1: 29-59.

Blum-Kulka, S., House, J. \& Kasper, G. (1989). Cross-cultural Pragmatics: Requests and Apologies. Norwood, NJ: Ablex Publishing Corporation.

Bouton, L. (1994). Conversational implicature in the second language: Learned slowly when not deliberately taught. Journal of Pragmatics, 22:157-67.

Braun, F. (1988). Terms of Address: Problems of Patterns and Usage in Various Languages and Cultures. Berlin: Mouton de Gruyter.

Boersma, D. (1994). Do chicken have lips? Conversational implicature in ESL classroom. Paper presented at the 8thAnnual Meeting of the International Conference on Pragmatics and Language Learning (Urbana, IL, 1994).

Brown, R. \& Gilman, A. (1960). The pronouns of power and solidarity. In P. P. Giglioli (Ed.), Language and society. Harmondsworth: Penguin, 252-282.

Chang, Y-F. (2008). How to say no: An analysis of cross-cultural difference and pragmatic transfer. Science Direct 31 : 477-493.

Cohen, A. D. \& Olshtain, E. (1981). Developing a measure of socio-cultural competence: the case of apology. Language Learning, 31:1.

Cohen, A. (1996). Developing the ability to perform speech acts. Studies in Second Language Acquisition,18: 253-267.

Félix-Brasdefer, C. (2008). Politeness in Mexico and the United States: A Contrastive Study of the Realization and Perception of Refusals. Amsterdam/Philadelphia: John Benjamins.

Félix-Brasdefer, C. (2009). Interlanguage refusals: Dispreferred responses in interlanguage pragmatics refusal sequences in learner-NS interactions. Applied Language Learning, 19: 1-27.

Gumperz, J. J. (1977). Sociocultural Knowledge in Conversational Inference. In: M. Saville-Troike (Ed.), 28th Annual Round Table Monograph Series on Languages and Linguistics. Washington, DC: Georgetown University Press. 191-211.

Gumperz, J. J. (1979). The sociolinguistic basis of speech act theory. In J. Boyd \& S. Ferrara (Eds.), Speech ActTen Years After. Milan: Versus. 101-121.

Halupka-Rešetar, S. (2013). Ispitivanje pragmatičke kompetencije studenata engleskog jezika struke [Exploring the pragmatic competence of ESP students]. In N. Silaški, \& T. Đurović (Eds.), Aktuelne teme engleskog jezika nauke i struke u Srbiji [Current topics in English for specific purposes at tertiary level in Serbia] Beograd: Centar za izdavačku delatnost Ekonomskog fakulteta. 215-228.

Halupka-Rešetar, S. (2014a). Request modification in the pragmatic production of intermediate ESP learners. ESP Today, 2(1): 65-79.

Halupka-Rešetar, S. (2014b).Compliment responses - a study of the pragmatic competence of advanced EFL students in Serbia. In T. Prćić et al. (Eds.), Engleski jezik $i$ anglofone književnosti u teoriji i praksi: zbornik radova u čast Draginji Pervaz [English Language and Anglophone Literatures in Theory and Practice: A Festschrift for Draginja Pervaz]. Novi Sad: Filozofski fakultet. 173-191.

Halupka-Rešetar, S. (2015). EFL learners' pragmatic competence in addressing the interlocutor. In B. Mišićllić\& V. Lopičić (Eds.), Jezik, književnost, diskurs: Jezičkaistraživanja[Language, Literature, Discourse: Papers in Linguistics]. Niš: Filozofskifakultet. 623-637.

Halupka-Rešetar, S. (2016). Testing EFL learners' understanding of conversational implicatures. In B. Mišić Ilić\& V. Lopičić (Eds.), Jezik, književnost, značenje. Jezička istraživanja [Language, Literature, Meaning: Papers in Linguistics]. Niš: Filozofski fakultet, 771-784.

Hofäcker, S. (2006). The Usage of Terms of Address in English: A Comparative Sociolinguistic Study. Available at: http://www.addressinenglish.naxx.net/project.html

House, J. (1982). Conversational strategies in German and English dialogues. In G. Nickel and D. Nehls (Eds.), Error Analysis. Constructive Linguistics and Second Language Learning (Special Issue of IRAL). Heidelberg: Julius Groos.

House, J. (2009). Subjectivity in English as lingua franca discourse: the case of you know. Intercultural Pragmatics, 6 (2): 171--194

House, J. (2013). Developing pragmatic competence in English as a lingua franca: Using discourse markers to express (inter)subjectivity and connectivity. Journal of Pragmatics, 59: 57-67.

House, J. \& Kasper, G. (1981). Politeness markers in English and German. In F. Coulmas (Ed.), Conversational Routines. The Hague: Mouton de Gruyter, 157-185.

Kasper, G. (1981). Pragmatische Aspekte in der Interimsprache. Tübingen: Günther Narr. 
Kasper, G. (1997). Can pragmatic competence be taught? (NetWork \#6) [HTML document]. Honolulu: University of Hawai'i, Second Language Teaching \& Curriculum Center. Available at: http://www.nflrc.hawaii.edu/ NetWorks/NW06/+-

Kitao, K. (1996). Communicative competence, preference organization, and refusals in British English. Sougou Bunka Kenkyujo Kiyou 13, 47-58.

Kwon, J. (2004). Expressing refusals in Korean and in American English. Multilingua, 23: 339-364.

Lee, S. J. (2002). Interpreting conversational implicatures: A study of Korean learners of English. The Korean TESOL Journal, 5: 1-26.

Lemmerich, E. (2010).An explicit awareness-raising approach to the teaching of sociopragmatic variation in early foreign language learning. PhD dissertation, University of Utah.

Nelson, G. L., Al Batal, M. \& El Bakary, W. (2002a). Directness vs. indirectness: Egyptian Arabic and US English communication style. International Journal of Intercultural Relations, 26: 39-57.

Nelson, G. L., Carson, J., Al Batal, M. \& El Bakary, W. (2002b). Cross-cultural pragmatics: Strategy use in Egyptian Arabic and American English refusals. Applied Linguistics, 23: 163-189.

Paunović, T. (2011). Intercultural communicative competence - beyond queen queueing and crumpets. In V. Vasić (Ed.), Jezik u upotrebi. Primenjena lingvistika u čast Ranku Bugarskom/ Language in use. Applied Linguistics in honour of Ranko Bugarski. Novi Sad: Društvo za primenjenu lingvistiku Srbije, Filozofski fakultet u Novom Sadu i Filološki fakultet u Beogradu, 231-252.

Paunović, T. (2013). The tangled web: Intercultural Communicative Competence. Niš: Faculty of Philosophy.

Rintell, E. (1997). Getting your speech act together: The pragmatic ability of second language Learners. Working Papers on Bilingualism, 17: 96-106.

Salazar, M. C., Safont-Jorda, M. \&Codina-Espurz, V. (2009). Refusal strategies: A proposal from a sociopragmatic approach. Revista Electronica de Linguistica Aplicada, 8: 139-150.

Savić, M. (2014). Politeness through the Prism of Requests, Apologies and Refusals: A Case of Advanced EFL Learners. Newcastle upon Tyne: Cambridge Scholars Publishing.

Stevens, P.B. (1993). The pragmatics of 'no!': some strategies in English and Arabic. IDEAL, 6: 87-112.

Taguchi, N. (2005). Comprehending implied meaning in English as a foreign language. The Modern Language Journal, 89: 543-562.

Takahashi, T. \& Beebe, L. M. (1987). The development of pragmatic competence by Japanese learners of English. JALT Journal, 8: 131-155.

Tannen, D. (1981). Indirectness in discourses: Ethnicity as conversation style. Discourse Processes, 4: 221-238.

Thomas, J. (1983). Cross-cultural pragmatic failure. Applied Linguistics, 4/2: 91-112.

Wolfson, N. (1981). Compliments in cross-cultural perspective. TESOL Quarterly, 15/2: 117-124.

Wolfson, N. (1989). Perspectives: Sociolinguistics and TESOL. Rowley, MA: Newbury House.

\section{APPENDIX \\ THE DCTS USED IN THE EXPERIMENT (KWON 2004):}

Please read the following 12 situations. After each situation you will be asked to write a response in the blank after 'You'.

1. You are the owner of a bookstore. One of your best workers asks to speak to you in private. Worker: As you know, I've been here just a little over a year now, and I know you've been pleased with my work. I really enjoy working here, but to be quite honest I really need an increase in pay.

You:

Worker: Well ... then I guess I'll have to look for another job.

2. You are a junior in college. You attend classes regularly and take good notes. Your classmate often misses class and asks you for the lecture notes.

Classmate: Oh God! We have an exam tomorrow but I don't have notes from last week. I am sorry to ask you this, but could you please lend me your notes once again?

You:

Classmate: Well ... then I guess I'll have to ask someone else. 
3. You are the president of a big printing company. A salesman from a printing machine company invites you to one of the most expensive restaurants, Lutece, in New York.

Salesman: We have met several times now, and I'm hoping you will buy my company's printing machine. Would you like to have dinner with me at Lutece to sign the contract? You:

Salesman: Well ... maybe we can meet another time.

4. You are an executive at a very large software company. One day the boss calls you into his office.

Boss: Next Sunday my wife and I are having a little party at my house. I know it's sudden ... but I'm hoping all my executives will be there with their wives/husbands. Will you come to the party?

You:

Boss: Well, that's too bad ... I was hoping everyone would be there.

5. You are at a friend's house watching TV. Your friend offers you a snack.

You: Thanks, but no thanks. I've been eating like a pig and I feel just terrible. My clothes don't even fit me.

Friend: Hey, why don't you try this new diet I've been telling you about?

You:

Friend: Well ... you should try it anyway.

6. Your boss just asked you to bring a report to him. You can't find the report on your desk because your desk is very disorganized. Your boss walks over.

Boss: You know, maybe you should try to organize yourself better. I always write things down on a piece of paper so I don't forget them. Why don't you try it?

You: (However, you don't like the boss' suggestion.)

Boss: Well ... it was only an idea anyway.

7. You arrive home and notice that your cleaning lady is extremely upset. She comes rushing up to you.

Cleaning lady: Oh God, I'm so sorry! I had a terrible accident. While I was cleaning, I bumped into the table and your china vase fell and broke. I feel very bad about it. I'll pay for it.

You: (Knowing that the cleaning lady is supporting three children.)

Cleaning lady: No, I'd feel better if I paid for it.

8. You teach English at a university. It is just about the middle of the semester now. One of your students asks to speak to you.

Student: Ah, excuse me, some of the students were talking after class yesterday. We kind of feel that the class would be better if you could give us more practice in conversation and less on grammar.

You:

Student: Well ... it was only a suggestion.

9. You are at a friend's house for lunch. Friend: How about another piece of cake?

You:

Friend: Come on, just a little piece?

You: 
10. A friend invites you to dinner, but you really don't like this friend's husband/wife. Friend: How about coming to my house Sunday night? We're having a small dinner party. You:

Friend: Well ... maybe next time.

11. You've been working in an advertising company now for some time. The boss offers you an increase in salary and a better position, but you have to move to another town. You don't want to go. Today, the boss calls you into his office.

Boss: I'd like to offer you an executive position in our new office in Hicktown. It's a great town only 3 hours from here by airplane! And, your salary will increase with the new position.

You:

Boss: Well ... maybe you should think about it some more before refusing.

12. You are at the office in a meeting with your boss. It is getting close to the end of the day and you want to leave the office.

Boss: If it's okay with you, I'd like you to spend an extra hour or two tonight so that we can finish up with this work. Can you stay little longer at the office?

You:

Boss: Well, that's too bad ... I was hoping you could stay.

\section{GOVORNI ČIN ODBIJANJA U PRODUKCIJI STUDENATA ENGLESKOG KAO JEZIKA STRUKE}

Govorni čin odbijanja se često upotrebljava u svakodnevnoj komunikaciji u najrazličitijim situacijama pa ne iznenađuje činjenica da postoji relativno obimna literatura vezana za diskursno pragmatička istraživanja ovog govornog čina. U ovom radu istražujemo u kojoj meri se produkcija govornog čina odbijanja kod studenata engleskog jezika struke razlikuje od produkcije izvornih govornika engleskog jezika u pogledu semantičkih formula koje se koriste, njihove frekvencije $i$ redosleda upotrebe. Nadalje, istraživanjem se želelo saznati $i$ u kojoj meri varijable društvenog statusa sagovornika i govornog čina koji prethodi odbijanju utiču na izbor strategije za odbijanje.

U istraživanju je učestvovalo 20 studenata Departmana za matematiku i informatiku Prirodnomatematičkog fakulteta u Novom Sadu, kojima je maternji jezik srpski, uzrasta su od 20 do 22 godine, nisu boravili duže od 3 meseca u zemlji u kojoj se govori engleski jezik, a u pogledu znanja engleskog, svi su na nivou B1-B2 (na osnovu ulaznog testa Quick placement test). Ispitanici su popunjavali test nadopunjavanja diskursa, sa zadacima u kojima smo varirali govorni čin koji prethodi odbijanju (zahtev ili poziv) i varijablu društvene moći.

Rezultati istraživanja pokazuju da studenti engleskog kao jezika struke koriste mnogo više strategija za odbijanje nego izvorni govornici engleskog jezika, ali uopšte ne koriste izraze zahvalnosti i pozitivne opaske, zbog čega govornicima engleskog jezika mogu zvučati grubo $i$ neotesano. Istovremeno, studenti engleskog kao jezika struke često daju objašnjenja i navode razloge za odbijanje ili se izvinjavaju, što rade i izvorni govornici engleskog jezika ali isključivo u odbijanju poziva ali ne i u odbijanju zahteva. Ono što je još karakteristično za studente engleskog kao jezika struke jeste dosledno nuđenje alternative uz odbijanje, što se u produkciji izvornih govornika engleskog jezika uopte ne uočava. Stoga smatramo da bi bilo neophodno u daljim istraživanjima usmeriti se na produkciju govornog čina odbijanja kod izvornih govornika srpskog jezika kako bi se ustanovilo da li su uočene karakteristike odbijanja na engleskom jeziku posledica transfera iz maternjeg jezika.

Ključne reči: pragmatička kompetencija, diskursna pragmatika, govorni činovi, odbijanje, engleski kao jezik struke 